\title{
DETERMINANTS FOR FINANCING IT FIRMS: A STUDY OF INDIAN INVESTORS
}

\author{
Shailendra Kumar ${ }^{1}$, Utkarsh Goel ${ }^{2}$ and Amar Johri ${ }^{3}$ \\ Department of Management Studies, Indian Institute of Information Technology (IIIT-A), INDIA. \\ shailendrak@iiita.ac.in \\ Department of Management Studies, Graphic Era University, India
}

\begin{abstract}
The present work is based on survey dataset of 104 investors who invests in various sector of the Indian economy along with IT sector in order to understand the selection process and evaluation criteria of investors towards IT sector in Indian context and to analyze the different dimensions of venture capitalists management and other investors based on risk return aspects, choice of investment firm, expected return on investment and financing mix. Our study gathered importance of selection factor and economic aspects of VCs in the selection process of IT firms and analyze the various other aspects of proposed investment. A designed questionnaire was sent to all investors who are the part of investment process. Factor Analysis and ANOVA has been used to obtain the results.
\end{abstract}

Keywords: Investment, IT Sector, Selection Process

\section{Introduction}

The growth and development of any sector largely depends on the fulfillment of funding requirement and availability of funding sources. In order to achieve the targeted future goals, it is important to continue with regular flow of capital in to the business concern. Initial and regular investment not only provide financial support but also helps to face the increasing completion, within the economic boundary and worldwide as well.

Availability of financial resources has been considered as an important aspect for continual growth and development. It has also been observed that availability of such funding resources is critical in most of the expansion activity. Different firms face various funding issues from different sources of funding agencies. In the spectrum of innovating source of finance, among the other mode of investment, venture capital is also emerging as an important innovating financial source for various sector of the economy.

Venture capital can be defined as a process through which the new highly risky startups are financial supported by investors in the overall development of business concern, in order to attract market opportunities and in obtaining long term capital gains (Shilson, 1984). Venture Capital, has been defined as a dedicated pools of capital which is independently managed and primarily has the interest in privately held, high-growth companies through investments in their equity, or equity-linked financial instruments (Lerner, 2009), and it also performs an important role in the commercial transformation of R\&D activities and is therefore proven catalyst for innovation (Christofidis and Debande, 2001). The founding editor and also an influential UK Venture capitalist of The Venture Capital Report (Reid, 1998) has further added: "venture capital is invested in high-risk venture (typically new companies and new technologies) ".

\section{Literature Review}

It is to be noted that the process of designing of business plan, its submission for investment purpose, review

Corresponding Author: Shailendra Kumar/shailendrak@iiita.ac.in 
and selection has been considered as one of the important aspect of investment decision. Most of the business plans are rejected by the investors because of multiple factors which investor demand in the proposed business plans. During the period of 1974 to 2016 number of studies have concluded in their research work that selection factors, investment objectives, investment dimensions and investment process are integral part of any investment decision making process. The present work is the mirror image of previous work who investigated the selection criteria, investment motives, significance of factors based on firm's structure and other dimensions of investment process.

In the selection process of business proposal, preference for evaluation process (Barry, 1994; Fried \& Hisrich, 1994), experience and personality of the entrepreneur, ownership and uniqueness of a product or service [Wells (1974), MacMillan et al. (1985), Ray (1991), Ray \& Turpin (1993), Ramón et al. (2007) where as MacMillan et al. (1985) and Muzyka et al. (1996) Fried \& Hisrich (1994) and Tyebjee \& Bruno (1984)], significance of market growth and its link to competitive advantage [Poindexter (1976) and Pandey \& Jang (1996)] and return on investment was given more importance. Shepherd (1999) highlighted that industrial experience has high importance. Shepherd (1999) determined the importance of factors which lead to success or failure with the venture and gathered various aspects such as managerial skills, product branding and market awareness. Lerner (2004), by reviewing all criteria gathered in previous studies focused on flexibility of business conditions so that venture can adjust in any adverse condition and could gain possible profitable opportunities. Worrall (2008) in his study emphasized on due-diligence as an important factor in order to complete valuation process of a company. Chen et al. (2009) in his study given strong preference to creation and submission of business plan and determined two major factors, business plan and project planning. Geronikolaou and Papachristou (2012) in his study obtained the significant relationship among VC investment and its relationship with patent. Faria and Barbosa (2014) investigated investment stage as one of the significant factor of investment proposal and also linked it to growth aspect of a business concern. Dutta and Folta (2016) described the relationship between business angles, venture capitalist and patent applications.

\section{Objectives of the Paper}

- To understand the importance of different dimensions of VC management team related with investment decision.

- To obtain the key selection and key investment criteria based on two major aspects: Entrepreneurs dimension and investment dimension

- To check the pattern and relationship among choice of factor and importance of factors.

4. Research Methodology

\section{1 "Data"}

The present study is exploratory and descriptive in nature. Primary and secondary sources have been used for study. Primary data is collected through a structured questionnaire, created with the help of identified factors resulted in previous empirical studies and was sent to various investors located in various metro cities of India. Secondary data is collected from various published literature, Journals, news papers and research articles.

\subsection{Analysis Tool}

For obtaining the different dimensions of investors in the selection process of IT firms in Indian context, gathering the factors affecting selection process and determining the investment motives, factor analysis has been used and to prove the relationship among choice of factors and its internal relationship, ANOVA has been used. 


\section{Results}

We have obtained the results on two major outcomes of the study. Firstly aspects of selection process and riskreturn factors related with investment decisions and relationship between choice of factors have been identified and second analytical study based on different dimension related with investment decision have been obtained.

\subsection{Results obtained through Factor Analysis}

To assess the importance of funding decision and investment process, we used factor analysis to reduce the variables. For understanding the evaluation criteria, total 32 variables were taken into considerations which were reduced in to 16 variables, grouped under four dimensions and for the determination of investment motives, total 42 variables were taken into consideration and were reduced in to 28 variables using factor analysis. Factor analysis has been used to obtain the number of variables. Factors have been extracted through principal analysis and rotated by means of Varimax, with Kaiser Normalization. The representation of the outcome of rotation process has been given as an appendix in Annexure 1 and Annexure 2.The formation of dimensions and creation of groups are given below in Table 3 and Table 4

Table 1Factors affecting evaluation criteria

\begin{tabular}{|c|c|c|c|c|}
\hline & \multicolumn{4}{|l|}{ FACTORS } \\
\hline & 1 & 2 & 3 & 4 \\
\hline & $\begin{array}{l}\text { Entrepreneur } \\
\text { pertaining to market } \\
\text { research }\end{array}$ & $\begin{array}{l}\text { Risk - Return and } \\
\text { investment strategies }\end{array}$ & $\begin{array}{l}\text { Branding and existence } \\
\text { of the product }\end{array}$ & Track Record \\
\hline \multirow{5}{*}{ Variaples } & $\begin{array}{l}\text { Demonstrated } \\
\text { leadership ability }\end{array}$ & $\begin{array}{l}\text { Capable of sustained } \\
\text { intense effort }\end{array}$ & $\begin{array}{l}\text { Personal compatibility } \\
\text { to me, Wells. }\end{array}$ & $\begin{array}{l}\text { Track record } \\
\text { relevant to venture. }\end{array}$ \\
\hline & $\begin{array}{l}\text { Demonstrated } \\
\text { managerial capabilities } \\
\text { in general business. }\end{array}$ & $\begin{array}{l}\text { Ability of evaluation } \\
\text { and reaction to risk. }\end{array}$ & $\begin{array}{l}\text { Entrepreneur referred } \\
\text { by trustworthy source. }\end{array}$ & \\
\hline & $\begin{array}{l}\text { Market has significant } \\
\text { growth rate. }\end{array}$ & $\begin{array}{l}\text { Venture provides exit } \\
\text { strategies. }\end{array}$ & $\begin{array}{l}\text { Product has been } \\
\text { developed to prototype. }\end{array}$ & \\
\hline & $\begin{array}{l}\text { Familiarity with } \\
\text { industry. }\end{array}$ & $\begin{array}{l}\text { Required return of } 10 \\
\text { times investment. }\end{array}$ & $\begin{array}{l}\text { Product has raw } \\
\text { material availability. }\end{array}$ & \\
\hline & $\begin{array}{l}\text { Resistance to economic } \\
\text { cycles. }\end{array}$ & $\begin{array}{l}\text { Required liquidity and } \\
\text { taken public. }\end{array}$ & $\begin{array}{l}\text { Venture will stimulate } \\
\text { existing market. }\end{array}$ & \\
\hline
\end{tabular}


Table 2 Investment Motives

\begin{tabular}{|c|c|c|c|c|}
\hline & \multicolumn{4}{|l|}{ Factors } \\
\hline & $\begin{array}{l}\text { Social and } \text { Economical } \\
\text { Development }\end{array}$ & Financial Motives & $\begin{array}{l}\text { Investment } \\
\text { appraisal and } \\
\text { evaluation }\end{array}$ & $\begin{array}{l}\text { Product } \\
\text { Branding }\end{array}$ \\
\hline \multirow[t]{16}{*}{ Variables $\Rightarrow$} & $\begin{array}{l}\text { Target an ownership position in } \\
\text { investee firm }\end{array}$ & Own return & $\begin{array}{l}\text { Discounted } \\
\text { value of free } \\
\text { cash flows }\end{array}$ & Investor return \\
\hline & 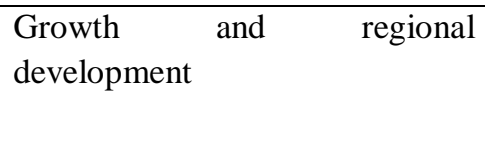 & $\begin{array}{l}\text { Experienced Forecast } \\
\text { of the likely future } \\
\text { value of the firm }\end{array}$ & $\begin{array}{l}\text { Risk of losing } \\
\text { entire } \\
\text { investment }\end{array}$ & $\begin{array}{l}\text { Promoting } \\
\text { entrepreneurs }\end{array}$ \\
\hline & Tax incentives & $\begin{array}{l}\text { Capitalized } \\
\text { maintainable earnings } \\
(\mathrm{P} / \mathrm{E} \text { multiple }\end{array}$ & $\begin{array}{l}\text { Risk of } \\
\text { unsuccessful } \\
\text { implementation } \\
\text { of the idea }\end{array}$ & $\begin{array}{lr}\text { Capable } & \text { of } \\
\text { high } & \text { profit } \\
\text { margin } & \end{array}$ \\
\hline & Fixed compensation, & $\begin{array}{l}\text { Capitalized } \\
\text { maintainable earnings } \\
\text { (P/E multiple }- \text { historic } \\
\text { basis) }\end{array}$ & $\begin{array}{l}\text { IT sector as a } \\
\text { growing sector }\end{array}$ & \\
\hline & Market capitalization & Future plans & & \\
\hline & $\begin{array}{l}\text { Latest transaction prices for } \\
\text { acquisition in the sector }\end{array}$ & & & \\
\hline & $\begin{array}{l}\text { Capitalized maintainable } \\
\text { earnings (EBIT multiple) }\end{array}$ & & & \\
\hline & $\begin{array}{l}\text { Industry's special rule of thumb } \\
\text { pricing ratio } \quad \text { (e.g. turnover } \\
\text { ratios) }\end{array}$ & & & \\
\hline & $\begin{array}{l}\text { Present value of future cash } \\
\text { flows }\end{array}$ & & & \\
\hline & $\begin{array}{l}\text { Risk of being unable to bail out, } \\
\text { if necessary }\end{array}$ & & & \\
\hline & Competitive risk & & & \\
\hline & leadership failure & & & \\
\hline & Market potentiality and links & & & \\
\hline & Resources and capabilities & & & \\
\hline & Risk taking capacity & & & \\
\hline & Leadership style & & & \\
\hline
\end{tabular}

\subsection{Results obtained through ANOVA}

Analysis of Variance is a technique to understand the relationship among the variables. In the present work, we used five point likert scale for obtaining the responses from investment firms. We observed the different investors have different opinions in their preference about the selection and evaluation criteria in the process of acceptance of an investment proposal. This difference is due to different aspects which are based on investment motives of investors. With the help of ANOVA, we proved the relationship among investor's investment motives, selection of aspects, identification of right business proposal and assignment of weights to all factor. Through ANOVA we obtained that different investors have their common preference in selection of different factors of investment motives, selection process, evaluation criteria, accepting or rejecting business proposal, deciding risk return aspects and creating funds for proposed investment decision. All investors have 
same opinion for investment motives but there are certain differences in terms of providing the range of selection and weights while selecting each factor. It has also been proved that selection of factors seem to be an important objectives in creation of business plan by IT firms in order to get their proposal funded by VCs. Results obtained by applying ANOVA has been given in the appendix.

\subsection{Analytical Results for Different Investment Motives}

Next we have also analyzed the other dimensions of VC management team to understand their preference about proposed investment sources, expected rate of return, compensation motive and financing mix.

\subsubsection{Preference in Investment source:}

In order to obtain the information about the preferred investment source, our survey collects the data considering 5 sectors of Indian economy such Information Technology sector, pharmaceutical sector, telecommunication sector, hospitality sector and infrastructure sector. The survey reported that $30 \%$ investors have their preferences in choosing information technology sector as investment destination, 14\% prefer pharmaceutical sector, $9 \%$ have their choice in telecommunication sector, $29 \%$ want to select hospitality sector and $18 \%$ have their preference in choosing infrastructure sector.

\subsubsection{Expected Average Rate of Return on Investment}

To understand the pattern and choice of investment desired by investors, our survey analyzes the data considering 5 different ranges of investment return. The survey reported that $40 \%$ investors have their preferences in getting $10 \%-20 \%$ returns, $35 \%$ look for $5 \%-10 \%$, $7 \%$ have their choice in generating $30 \%$ returns and $18 \%$ want to $20 \%-30 \%$ returns.

\subsubsection{Compensation Management}

To obtain the desire about the needed compensation by investors, our survey reported that $48 \%$ investors have their preferences in getting good returns on investment, $24 \%$ investors are interest in receiving management fee, $17 \%$ look for growth in proposed value of investment and $11 \%$ proceed for equity stake.

\subsubsection{Financing Mix for Proposed Fund Requirement}

Total 6 instruments have been used for this purpose such as equity capital, convertible debt, shareholder's contribution, loans with separable option, preferred stock and participating loan. Out of our respondents, $19 \%$ prefer to raise funds from equity capital, $19 \%$ from convertible debt, and 12\% from shareholder's contribution, $22 \%$ from loans with separable option, $23 \%$ from preferred stock and $5 \%$ from participating loan.

\subsubsection{Strategies for Exit Plans}

To understand the decisions about the strategies towards exit plan from investment destination, our survey determined that of various options such as Initial public offer, buy back, trade sale and structural change in investment, $20 \%$ investors are interest for initial public offer, $46 \%$ have their choices in acquisition or trade sale, $14 \%$ look for secondary sale, $11 \%$ want to go for buyback and $9 \%$ investors are interested for reconstruction of investment.

\subsubsection{Stage wise choice of investment}

In order to understand the investment choice of investors during selection of preferred stage of investment, our study obtained that out of all stages of venture capital investment proves, $30 \%$ have their preferences in selecting seed stage for investment purpose, 17\% look for startup stage, 17\% choose expansion stage, 19\% have their preferences for replacement stage and $17 \%$ target exit stage for their investment preferences. 


\section{Conclusions}

The present work determines the investment motives and evaluation criteria of VCs and other investors in order to select IT firms in Indian context and analyzes their risk return and investment dimensions related with proposed investment. Our results gathered that choice of factors among different investors remains same and selection of aspects to individual firms differ. We find that entrepreneurs capability, designing of business plan, risk return relationship, market research, branding of product, acceptability of the product and track record of the firm plays very important role in the evaluation process of firms and investors give due care to all factors during their screening process.

Factor analysis resulted with most important investment motives and evaluation criteria and ANOVA resulted with a relationship between choice of aspects and their impact on assignment of weights.

The results will have a positive impact in the designing of business plans by IT firms in order to attract more investment by traditional and modern sources of investment and will also help investors to understand the firm's qualitative aspects in a prescribed manner.

References.

Barry, C.B. (1994). New directions in research on venture capital finance. Financial Management, 3 (23), 3-15.

Brophy, D. J. 1986, "Venture Capital Research," in Sexton \& R. W. Smilor eds., The Art \& Science of Entrepreneurship, pp. 119-143.

Carter, R.B. and Van Auken, H.E. (1994). Venture capital firms' preferences for projects in particular stages of development. Journal of Small Business Management, 32 (1), 60-74.

Charles River Associates. 1976, “An Analysis of Venture Capital Market Imperfections,” NTIS Report PB254996, National Bureau of Standards, Washington, D.C.

Chen, X.-P., Yao, X., \& Kotha, S. (2009). "Entrepreneurship passion and preparedness in business plan presentations: A persuasion analysis of venture capitalists' funding decisions," Academy of Management Journal, 52 (1), 199-214.

Chotigeat, T. \& Pandey, I. M. 1997, "Venture Capital Investment Evaluation in Emerging Markets," Multinational Business Review, Vol. 5, pp. 54-62.

Dorsey, T. K. 1977, "The Measurement and Assessment of Capital Requirements, Investment Liquidity and Risk for the Management of Venture Capital Funds," unpublished doctoral dissertation, University of Texas, Austin.

Dutta, S.; Folta, T. B. (2016). "A comparison of the effect of angels and venture capitalists on innovation and value creation", Journal of Business Venturing, 31(1), pp. 39-54. doi:10.1016/j.jbusvent.2015.08.003.

Elango, B., Fried, V.H., Hisrich, R.D., and Polonchek, A. (1995). How venture capital firms differ. Journal of Business Venturing, 10, 157-179.

Fahy, John 2000, "The resource-based view of the firm: some stumbling-blocks on the road to understanding sustainable competitive advantage”, Journal of European Industrial Training, vol. 24, no. 2/3/4, pp. 94-104.

Faria, A. P.; Barbosa, N. (2014). "Does venture capital really foster innovation?” Economics Letters, 122, pp. 129 - 131, doi:10.1016/j.econlet.2013.11.014.

Feeney, L., Haines, G. H. Jr., \& Riding, A. L. 1999, "Private Investors' Investment Criteria: Insights from Qualitative Data," Venture Capital, Vol. 1, pp. 121-145.

Fried V. H. \& Hisrich R. D. (1994). "Toward a model of venture capital investment decision making," Financial Management, Vol. 23, pp. 28-37.

Geronikolaou, G., \& Papachristou, G. (2012). "Venture capital and innovation in Europe", Modern Economy, 
3(4), 454-459. doi:10.4236/me.2012.34058.

Goslin, L. N. \& Barge, B. 1986, "Entrepreneurial Qualities Considered in Venture Capital Support," proceedings from Babson Research Conference, pp. 366-379.

Hair, J.F., Black, W.C., Babin, B.J., Anderson, R.E., and Tatham, R.L. (2006). Multivariate data analysis. Upper Saddle River, NJ: Prentice Hall.

Hall, J. \& Hofer, C. W. 1993, "Venture Capitalists' Decision Criteria in New Venture Evaluation" Journal of Business Venturing, Vol. 8, pp. 25-42.

Hoffman, C. A. 1972, "The Venture Capital Investment Process: A Particular Aspect of Regional Economic Development," unpublished doctoral dissertation, University of Texas, Austin.

Hoskisson, Robert E., Hitt, Michael A., Wan, William P. \& Yiu, Daphne 1999, "Theory and research in strategic management: Swings of a pendulum", Journal of Management, vol. 25, no. 3, pp. 417-456.

Karsai, J. \& Wright, M. 1998, "Screening and Valuing Venture Capital Investment: Evidence from Hungary, Poland and Slovakia," Entrepreneurship \& Regional Development, Vol 10, No. 3, pp. 203-224.

Khan, A. M. 1987, "Assessing Venture Capital Investments with Non compensatory Behavioral Decision Models," Journal of Business Venturing, Vol. 2, pp. 193-205.

Knight, R. M. 1994, "Criteria Used by Venture Capitalists: A Cross Cultural Analysis," International Small Business Journal, Vol. 13, pp. 26-37.

Kierulff, H. 1986, “Additional Directions for Research in Venture Capital," in Sexton \& R. W. Smilor eds., The Art \& Science of Entrepreneurship, pp. 145-149.

Lerner, J. (2004). When bureaucrats meet entrepreneurs: The design of effective "public venture capital" programs. In D. Holtz-Eakin \& H. S. Rosen (Eds.), Public Policy and the Economics of Entrepreneurship (pp. 1-22). Cambridge, MA: The MIT Press.

MacMillan, I. C., Siegel, R. \& Subba Narasimha, P. N. 1985, "Criteria Used by Venture Capitalists to Evaluate New Venture Proposals," Journal of Business Venturing, Vol. 1, pp. 119-128.

MacMillan, I. C., Zemann, L. \& Subbanarasimha, P. N. 1987, "Criteria Distinguishing Successful Ventures in the Venture Screening Process," Journal of Business Venturing, Vol. 2, pp. 123- 137.

Manigart, S. \& Wright, M. 1997, "Venture Capitalists' Appraisal of Investment Projects: An Empirical European Study," Entrepreneurship: Theory and Practice, Vol. 21, No. 3, pp. 29-43.

Muzyka, D., Birley, S. \& Leleux, B. 1996, "Trade-offs in the Investment Decisions of European Venture Capitalists," Journal of Business Venturing, Vol. 11, No. 4, pp. 273-288.

Oliver, Christine 1997, "Sustainable Competitive Advantage: Combining Institutional and Resource Based Views", Strategic Management Journal, vol. 18, no. 9, pp. 697-713.

Pandey, I.M. and Jang, A. (1996)."Venture capital for financing technology in Taiwan,” Technovation, 16 (9), 499-514.

Poindexter, J. B. 1976, "The Efficiency of Financial Markets: The Venture Capital Case," unpublished doctoral dissertation, New York University, New York.

Rah, J., Jung K. \& Lee, J. 1994, "Validation of the Venture Evaluation Model in Korea," Journal of Business Venturing, Vol. 9, pp. 509-524.

Ray, D. M. \& Turpin, D. V. 1992, "Venture Capital in Japan," International Small Business Journal, Vol. 11, pp. 39-56.

Ramón, T., Garcia, D., and Van Auken, H.E., (2007). "Venture capital in Spain by stage of development," Journal of Small Business Management, 45 (1), 68-88.

Ruhnka, J. C. \& Young, J. E. 1991, "Some Hypotheses about Risk in Venture Capital Investing," Journal of Business Venturing, Vol. 6, pp. 115-133. 
Shepherd, D. A. (1999). "Venture capitalists' introspection: A comparison of "in use" and "espoused" decision policies," Journal of Small Business Management, 37 (2), 76-87.

Siskos, J. \& Zopounidis, C. 1985, "The Evaluation Criteria of the Venture Capital Investment Activity: An interactive Assessment," European Journal of Operational Research, Vol. 31, pp. 304-313.

Stevenson, H. H., Muzyka, D. F. \& Timmons, J. A. YEAR "Venture Capital in Transition: A Monte- Carlo Simulation of Changes in Investment Patterns," Journal of Business Venturing, Vol. 2, pp. 103-121.

Timmons, J. \& Gumpert, D. 1982, "Discard Many Old Rules about Getting Venture Capital,” Harvard Business Review, Vol. 8.

Tyebjee, T. T. \& Bruno, A. V. 1981, "Venture Capital Decision-Making: Preliminary Results form Three Empirical Studies," Frontiers of Entrepreneurship Research, Babson College, Massachusetts.

Tyebjee, T. T. \& Bruno, A. V. 1984, "A Model of Venture Capitalist Investment Activity," Management Science, Vol. 30, pp. 1051-1066.

Walley, Keith \& Thwaites, Des 1996, "A review, synthesis and interpretation of the literature on competitive advantage", Journal of Strategic Marketing, vol. 4, pp. 163-179.

Wells, W. A. 1974, "Venture Capital Decision Making," unpublished doctoral dissertation, Carnegie Mellon University.

Wetzel, W. E. Jr. 1982, "Risk Capital Research" in C. A. Kent, D. L. Sexton, \& K. H. Vesper eds., Encyclopedia of Entrepreneurship, pp. 140-164.

Worrall, C. (2008, February 8). Startups raising venture capital - Due diligence. Retrieved July 5, 2011 from http://ezinearticles.com/?Startups-Raising-Venture-Capital---Due-Diligence \& id=972516.

Wright, J. F. 2002, "Monte Carlo Risk Analysis and Due Diligence of New Business Venture," American Management Association, New York.

Zacharakis, A. L. \& Meyer, G. D. 2000, "The Potential of Actuarial Decision Models: Can They Improve the Venture Capital Investment Decision?” Journal of Business Venturing, Vol. 15. 


\section{$\underline{\text { Appendix }}$}

Appendix 1: Factor Loading for Evaluation Criteria

Factor Loadings of Variables in Four Dimensions

\begin{tabular}{|c|c|c|c|c|}
\hline \multirow[t]{2}{*}{ Variables } & \multicolumn{4}{|c|}{ Factors } \\
\hline & 1 & 2 & 3 & 4 \\
\hline Leadership skills & .934 & & & \\
\hline Managerial skill related with the business & .962 & & & \\
\hline Productive growth rate & .935 & & & \\
\hline Industry exposure & .962 & & & \\
\hline Economic conditions and adoptability & .934 & & & \\
\hline Efforts for generating returns from market & & .755 & & \\
\hline Risk - return analysis and its evaluation & & .986 & & \\
\hline Planning for exit opportunities & & .986 & & \\
\hline 10 times return from proposed investment & & .780 & & \\
\hline Liquidity profitability trade off and taken public & & .986 & & \\
\hline Compatibility features with investors & & & .869 & \\
\hline Entrepreneur reference source & & & .939 & \\
\hline Preface to product development & & & .913 & \\
\hline Raw material conditions & & & .939 & \\
\hline To gain market opportunities & & & .913 & \\
\hline Ventures track record & & & & .921 \\
\hline
\end{tabular}

Source: Extraction Method: Principal Component Analysis.

Rotation Method: Varimax with $\quad$ Kaiser $\quad$ Normalization.



Factor Loadings of Variables in Four Dimensions

\begin{tabular}{|c|c|c|c|c|}
\hline \multirow{2}{*}{ Variables } & \multicolumn{4}{|c|}{ Factors } \\
\hline & 1 & 2 & 3 & 4 \\
\hline Desire of ownership position & 0.756 & & & \\
\hline Positive growth and development on regional basis & 0.818 & & & \\
\hline Tax implication and incentives & 0.972 & & & \\
\hline Investment returns & 0.844 & & & \\
\hline Market capitalization rate & 0.880 & & & \\
\hline Acquisition and its transaction price & 0.844 & & & \\
\hline Earnings before interest and tax & 0.818 & & & \\
\hline Analysis or turnover ratio & 0.880 & & & \\
\hline Predictive cash flow & 0.928 & & & \\
\hline Risk of being unable to bail out & 0.772 & & & \\
\hline Risk of intense competition & 0.880 & & & \\
\hline Risk of leadership failure & 0.764 & & & \\
\hline Market awareness & 0.818 & & & \\
\hline Available resources & 0.899 & & & \\
\hline Risk bearing capacity & 0.972 & & & \\
\hline Leadership traits & 0.972 & & & \\
\hline Internal returns & & 0.985 & & \\
\hline Evaluation of future value of the firm & & 0.966 & & \\
\hline Price- earnings ratio & & 0.985 & & \\
\hline Evaluation of Capitalized maintainable earnings & & 0.985 & & \\
\hline Planning directions for future & & 0.911 & & \\
\hline Discounted value of future cash flow, free or tax based & & & 0.988 & \\
\hline Risk of investment lost & & & 0.988 & \\
\hline Risk of idea implementation & & & 0.988 & \\
\hline Growing capacity of IT sector & & & 0.988 & \\
\hline Investor return & & & & 0.986 \\
\hline Promotional factors of entrepreneurs & & & & 0.986 \\
\hline Evaluation of profit margin & & & & 0.903 \\
\hline
\end{tabular}

Extraction Method: Principal Component Analysis.

Rotation Method: Varimax with Kaiser Normalization.

Appendix 3 RESULTS OF ANOVA

ANOVAs: Two-Factor Without Replication 


\begin{tabular}{|c|c|c|c|c|c|c|}
\hline Summary & Count & Sum & Average & Variance & & \\
\hline F1 & 8 & 35.12 & 4.39 & 0.010628571 & & \\
\hline $\mathrm{F} 2$ & 8 & 32.34 & 4.0425 & 0.007364286 & & \\
\hline F3 & 8 & 33.98 & 4.2475 & 0.001135714 & & \\
\hline F4 & 8 & 36.3 & 4.5375 & 0.008392857 & & \\
\hline Financers & 4 & 17.26 & 4.315 & 0.0233 & & \\
\hline Financial Consultants & 4 & 17.28 & 4.32 & 0.109333333 & & \\
\hline Financial Institutions & 4 & 17.38 & 4.345 & 0.027833333 & & \\
\hline Fund Managers & 4 & 17.28 & 4.32 & 0.060266667 & & \\
\hline Private Banks & 4 & 17.12 & 4.28 & 0.055466667 & & \\
\hline Public Banks & 4 & 17.14 & 4.285 & 0.081166667 & & \\
\hline $\mathrm{VCs}$ & 4 & 17.1 & 4.275 & 0.013966667 & & \\
\hline Others & 4 & 17.18 & 4.295 & 0.0433 & & \\
\hline \multicolumn{7}{|l|}{$\underline{\text { ANOVA }}$} \\
\hline Source of Variation & $\underline{S S}$ & $d f$ & $\underline{M S}$ & $\underline{F}$ & P-value & F crit \\
\hline Rows & 1.0679375 & 3 & 0.355979167 & 42.48383889 & $4.26 \mathrm{E}-09$ & 3.072467 \\
\hline Columns & 0.0166875 & 7 & 0.002383929 & 0.284506642 & 0.952887 & 2.487578 \\
\hline Error & 0.1759625 & 21 & 0.008379167 & & & \\
\hline Total & 1.2605875 & 31 & & & & \\
\hline
\end{tabular}

Appendix 4 RESULTS OF ANOVA

\begin{tabular}{|l|l|l|l|l|l|l|}
\hline \multicolumn{6}{|l|}{ ANOVAs: Two-Factor Without Replication } \\
\hline Summary & $\underline{\text { Count }}$ & $\underline{\text { Sum }}$ & $\underline{\text { Average }}$ & $\underline{\text { Variance }}$ & & \\
\hline F 1 & 7 & 28.6063 & 4.08661 & 0.00507 & & \\
\hline F 2 & 7 & 29.94 & 4.27714 & 0.02259 & & \\
\hline F 3 & 7 & 28 & 4 & 0 & & \\
\hline F 4 & 7 & 33.5 & 4.78571 & 0.01032 & & \\
\hline $\begin{array}{l}\text { Financial } \\
\text { Consultant }\end{array}$ & 4 & 16.675 & 4.16875 & 0.08391 & & \\
\hline $\begin{array}{l}\text { Financial } \\
\text { Institution }\end{array}$ & 4 & 17.3058 & 4.32646 & 0.1368 & & \\
\hline Fund Manager & 4 & 17.2488 & 4.31219 & 0.09101 & & \\
\hline Private Bank & 4 & 16.9838 & 4.24594 & 0.19694 & & \\
\hline Public Bank & 4 & 17.1688 & 4.29219 & 0.13108 & & \\
\hline VC & 4 & 17.3058 & 4.32646 & 0.1368 & & \\
\hline OTHERS & 4 & 17.3583 & 4.33958 & 0.13627 & & \\
\hline ANOVA & & & & & & \\
\hline
\end{tabular}


Shailendra Kumar, Utkarsh Goel and Amar Johri / Determinants for Financing IT Firms: A Study of Indian Investors

\begin{tabular}{|l|l|l|l|l|l|l|}
\hline $\begin{array}{l}\text { Source } \\
\text { Variation }\end{array}$ & $\underline{S S}$ & $\underline{\underline{S S}}$ & $\underline{M S}$ & $\underline{F}$ & $\underline{\text {-value }}$ & $\underline{\underline{\text { crit }}}$ \\
\hline Rows & 2.599372 & 3 & 0.866457 & 112.1727 & $7.72 \mathrm{E}-12$ & 3.159908 \\
\hline Columns & 0.088834 & 6 & 0.014806 & 1.91676 & 0.133009 & 2.661305 \\
\hline Error & 0.139038 & 18 & 0.007724 & & & \\
\hline Total & 2.827244 & 27 & & & & \\
\hline
\end{tabular}

